\title{
Sustainability of Sheep Fleece Utilization in Jordan as an Insulation Material to Decrease Environmental Pollution, Increase Farmers' Income, and Create New Job Opportunities
}

\author{
Bahieh M. Alma'atah, Taha M. Alkhamis* \\ Department of Chemical Engineering, Mutah University, Mutah, Karak, Jordan \\ Email: *alkhamis@mutah.edu.jo
}

How to cite this paper: Alma'atah, B.M. and Alkhamis, T.M. (2020) Sustainability of Sheep Fleece Utilization in Jordan as an Insulation Material to Decrease Environmental Pollution, Increase Farmers' Income, and Create New Job Opportunities. Journal of Environmental Protection, 11, 821-837.

https://doi.org/10.4236/jep.2020.1110051

Received: July 30, 2020

Accepted: October 11, 2020

Published: October 14, 2020

Copyright $\odot 2020$ by author(s) and Scientific Research Publishing Inc. This work is licensed under the Creative Commons Attribution International License (CC BY 4.0).

http://creativecommons.org/licenses/by/4.0/

\begin{abstract}
This study is planned to investigate the problems associated with the wasted sheep fleece in Jordan and to suggest methods to decrease its environmental impact. Results indicate that sheep fleece in Jordan makes an excellent resource for buildings insulation material. A linear regression model is used to predict sheep number for the period (2017-2030). Based on the predicted number of Sheep an estimated annual average production of wool is found for the period (2017-2030) to be ( $3.586 \times 10^{3}$ ton). The average cost per $\mathrm{kg}$ of fleece produced is calculated to be $0.39 \mathrm{JD}$, and the estimated price of fleece per head, if market is available for raw fleece, is 1 JD. Average annual financial losses by farmers are calculated to be $\left(3.743 \times 10^{6} \mathrm{JD}\right)$ for the period 2002-2016, and they were estimated to be $\left(9.421 \times 10^{6} \mathrm{JD}\right)$ for the years 2017-2030. Physical characteristics of sheep-wool are presented and compared to other competitive insulation materials (polystyrene and rockwool). Sustainability of sheep-wool production to be utilized as an insulation material is found to be an excellent solution to the huge waste of wool with respect to farmers and National income and to the problems associated with environmental impact. Results can be generalized to similar cases worldwide.
\end{abstract}

\section{Keywords}

Sheep Fleece, Insulation Material, Natural Resources, Environmental Pollution, Jordan

\section{Introduction}

Sheep plays a very important role in the life of humanity. Besides providing 
dairy food, they provide sustainable source of wool for many purposes. About 90 percent of sheep worldwide produce wool in addition to dairy products and meat [1]. The total worldwide production of clean wool reported is about $3.14 \times$ $10^{9}$ pounds [2]. The average composition wool is $50 \% \mathrm{C}, 22 \%-25 \% \mathrm{O}, 16 \%-$ $17 \% \mathrm{~N}, 7 \% \mathrm{H}$, and $3 \%-4 \% \mathrm{~S}$ [3]. Sheep wool characteristics depend on the type of species that produces it, and the type of wool usually determines the best way for utilization [3]. Roughness, elasticity, fiber length, and fiber thickness are the main properties used to classify wool and to determine its uses [4] [5] [6]. Excellent types of wool are used to produce excellent clothing material. Most of apparel wool (about $80 \%$ ) is produced in countries like Australia, New Zealand, China, Former Soviet Union countries, and Uruguay [6].

Carpets and blankets are made of wool produced by several breeds, but mostly by Awassi, which is a type of non-European origin and widely spread in southwest of Asia, especially in the Arabian Desert [7] [8]. The main purpose of acquisition of this breed is for dairy products and meat [9]. The range of stable length and diameter of Awassi wool fibers are $(10-19 \mathrm{~cm})$ and $(30-45 \mu \mathrm{m})$, respectively [5]. The Awassi breed wool is considered as part of the $41 \%$ sheep wool produced worldwide [1]-[9]. Jordanian Awassi wool is of this type, which can be used only in carpet and blanket production, because its average fiber length is about $15 \mathrm{~cm}$ and its average fiber diameter is about $34 \mu \mathrm{m}$ [5]. The weight of fleece produced by head of Awassi breed ranges between 1.5 and $3 \mathrm{~kg}$ [3]; however, a study on Jordanian sheep reported a value of $2.5 \mathrm{~kg} / \mathrm{head}$ [10].

People of Jordan used to make bed mattresses and quilts from sheep wool. Also, they used to weave tents out of sheep wool as well as goat hair. These types of tents are used to protect people in winter rainy seasons and summer sunny seasons. However, modern style of living forced people to abandon sheep wool in favor of synthetic materials, which makes farmers exposed to two major challenges. The first one is the reduction of his yearly income because of closing the door to national fleece market, and the second is the accumulation of waste wool material. Therefore, sheep breeders are forced to burning the accumulated waste. As a solution, several sheep owners, burn their wool crop every year [11].

Besides the above problems that face sheep breeders, the environment also suffers from fleece waste accumulation. Burning such waste, launches several unwanted gases such as $\mathrm{CO}_{2}, \mathrm{NO}_{\mathrm{x}}$, and $\mathrm{SO}_{2}$. Moreover, the other problem is the pollution by un-burned fleece, which cannot be decomposed easily, since it is reported that, the average time it takes to decompose such material is about fifty years [12].

Due to the economic circumstances experienced by Jordan as a country and the economic hardships that face the people, measures must be taken to create job opportunities and suitable market for the huge production of fleece every year. Only one previous study considered the fleece accumulation problem [10]. The study included the feasibility of establishing a firm that collects the produced fleece and exports it as raw material. Although the study was carried out in 2003, no investor even thought to consider starting it. The reason, we believe, 
is that the specifications of Jordanian sheep wool are not suitable for the clothing world market.

Therefore, the first objective of this study is to investigate the serious problems facing sheep Breeders with sheep fleece collection and the associated impact of its disposing on the environment. The second objective is to prove sustainability of wool production and to investigate Jordanian sheep-wool thermal characteristics. The third objective is to suggest solutions to the above problems through technology transfer.

\section{Methodology}

Data associated with specific objectives were obtained from different sources. First, Annual sheep numbers and their distribution were obtained from the statistical yearbook of Jordan [13]. Then, other data required were obtained from farmers' interviews, Jordan Industrial Estate Company (JIEC), and interviews of former glass wool (insulation material) factories owners in Jordan which had been closed for different reasons. After that, a simple mathematical regression model was used to predict the number of Sheep for the period (2017-2030). Also, experiments were performed to investigate the thermal characteristics of Jordanian sheep-wool and other thermal insulation materials that are used in the construction market in Jordan. Moreover, major sources of financial and environmental problems associated with sheep wool were investigated through local reports and sheep breeders' interviews. Finally, results were presented, discussed, and solutions were suggested.

\subsection{Sheep Numbers and Distribution}

Total number of Sheep and their distribution over all Jordanian northern, central, and southern regions were obtained from the statistical yearbook (2002-2016) (Department of Statistics) (DOS) [13] (Table 1). Northern region shows the highest percentage of Sheep holdings, and therefore the corresponding highest fleece production.

The distribution of the average number of Sheep with respect to Jordanian Governorates (2002-2016) is presented in Figure 1. Hence, these data are used, in part, to decide on the location of the proposed industrial firm to produce a sustainable thermal insulation material. It is obvious that the lowest percent of sheep holdings is seen to be associated with Jerash governorate and the highest is in Mafraq governorate. Therefore, Mafraq governorate has an excellent potential to be an optimum incubator of sheep-wool thermal-insulation industry.

The total number of Sheep is observed to increase with time. The percent increase between 2002 and 2006 is about 38\%, between 2006 and 2011 is about 15\%, and between 2011 and 2016 is 44\%. The average increase of sheep number is about $33 \%$ every 5 to 6 years.

\subsection{Mathematical Model}

To investigate the sustainability of sheep wool for any possible manufacturing 
Table 1. Total and percentage of sheep holdings for northern, central, and southern regions.

\begin{tabular}{|c|c|c|c|c|}
\hline Year & Southern Region & Northern Region & Central Region & Total \\
\hline 2002 & 203,530 & 642,270 & 587,510 & $1,433,310$ \\
\hline 2003 & 256,960 & 717,420 & 502,070 & $1,476,450$ \\
\hline 2004 & 222,100 & 845,380 & 461,600 & $1,529,080$ \\
\hline 2005 & 321,440 & $1,007,240$ & 562,280 & $1,890,960$ \\
\hline 2006 & 259,260 & $1,001,710$ & 710,550 & $1,971,520$ \\
\hline 2007 & 282,670 & $1,195,340$ & 773,440 & $2,251,450$ \\
\hline 2008 & 610,060 & 810,440 & $1,072,860$ & $2,493,360$ \\
\hline 2009 & 479,810 & 733,180 & 857,950 & $2,070,940$ \\
\hline 2010 & 590,300 & 761,540 & 823,850 & $2,175,690$ \\
\hline 2011 & 550,190 & 824,550 & 889,860 & $2,264,600$ \\
\hline 2012 & 564,400 & 828,970 & 840,610 & $2,233,980$ \\
\hline 2013 & 508,230 & 851,730 & 951,190 & $2,311,150$ \\
\hline 2014 & 588,730 & 999,650 & $1,091,890$ & $2,680,270$ \\
\hline 2015 & 568,300 & 962,710 & $1,065,430$ & $2,596,440$ \\
\hline 2016 & 765,190 & $1,161,480$ & $1,335,760$ & $3,262,430$ \\
\hline Total & $6,771,170$ & $13,343,610$ & $12,526,850$ & $32,641,630$ \\
\hline$\%$ & 20.7 & 40.9 & 38.4 & $100 \%$ \\
\hline
\end{tabular}

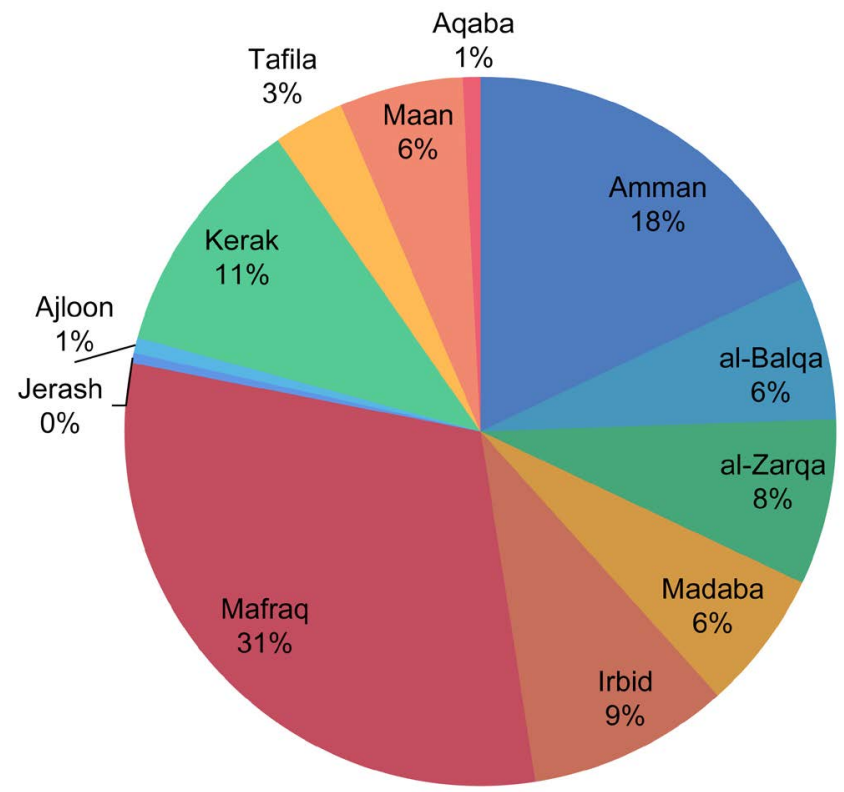

Figure 1. Distribution of sheep in Jordanian Governorates.

product, a mathematical model is to be used to predict the future sheep number. Two mathematical models were investigated. The first one was the exponential growth model, and the second was the linear regression model. The general equ- 
ation of the exponential growth model is [14]:

$$
P=P_{0} \mathrm{e}^{K t}
$$

where $K$ is Malthus factor, $P$ is the sheep number, $P_{0}$ is the number at $t_{0}$, and $t$ is time in years.

Excel sheet was used to solve for the Equation (1) using available data (2002-2016) to get $K$ and $R^{2}$ as:

$$
P=1.4884090 \times 10^{6} \mathrm{e}^{0.05 t}, R^{2}=0.81
$$

Figure 2 shows the results of the exponential growth model for the examined period (2002-2016) and the forecasted period (2017-2030).

The exponential growth model was compared to the linear regression model that follows the linear equation:

$$
y=b x+a
$$

where: $b$ is the regression line slope and $a$ is the intercept. The constants $a$ and $b$ are calculated from the following equations:

$$
\begin{aligned}
& a=\frac{\sum y}{n} \\
& b=\frac{\sum x y}{\sum x^{2}}
\end{aligned}
$$

The Analysis of Variance for Simple Linear Regression requires calculation of Some of Square due to Regression (SSR), Sum of Square Residuals or Errors (SSE) and Total Sum of Square deviation (SST) by the following equations:

$$
\begin{gathered}
\mathrm{SSR}=\sum(\hat{y}-\bar{y})^{2} \\
\mathrm{SSE}=\sum\left(y_{i}-\hat{y}_{i}\right)^{2} \\
\mathrm{SST}=\mathrm{SSR}+\mathrm{SSE} \\
R^{2}=\frac{\mathrm{SSR}}{\mathrm{SST}} \text { or }=\frac{\mathrm{SSR}}{\mathrm{SSR}+\mathrm{SSE}}
\end{gathered}
$$

Equation (3) was solved to obtain $a$ and $b$ using excel sheet and available data (2002-2016) as:

$$
y=97761.49 x+1.4884090 \times 10^{6}
$$

Figure 3 shows the results of Equation (10) up to the year 2030 and the exact sheep numbers (2002-2016).

To investigate the accuracy of the forecasting of both models, the mean absolute percentage error (MAPE) was calculated for both models as:

$$
\text { MAPE }=\frac{1}{n} \sum_{t=1}^{n}\left|\frac{y_{t}-f_{t}}{y_{t}}\right| \times 100
$$

where, $y_{t}$ is the actual value and $f_{t}$ is the forecast value. MAPE values for the exponential growth model and the linear regression model are reported in Table 2. The average value of MAPE for exponential growth model was $7.51 \%$, whereas it was $7.49 \%$ for the linear regression model. 


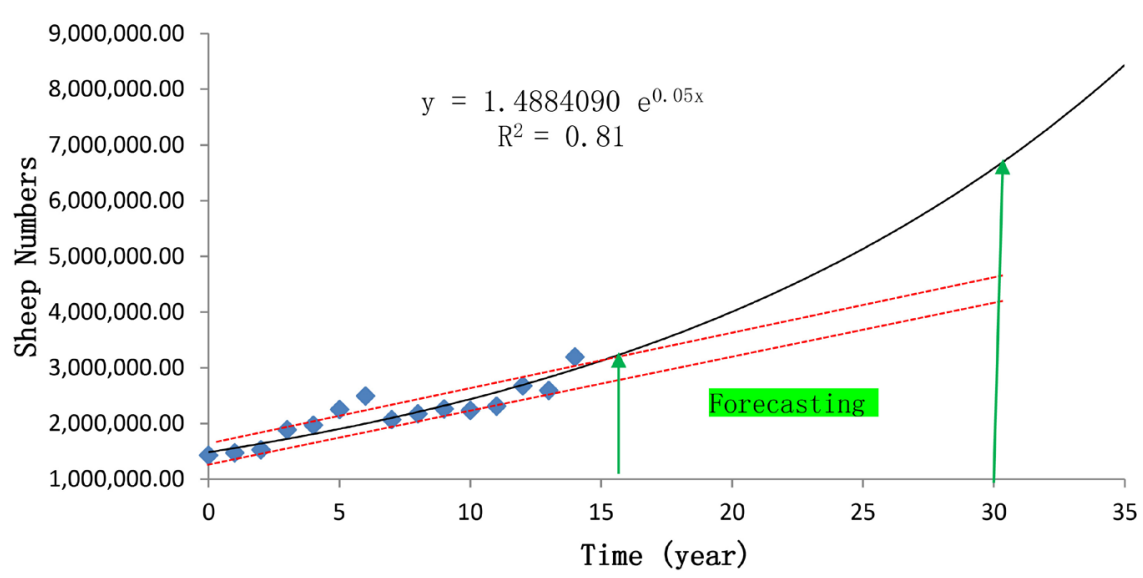

Figure 2. The results of the exponential growth model showing the real data of sheep number compared to the predicted values and the forecasting sheep number.

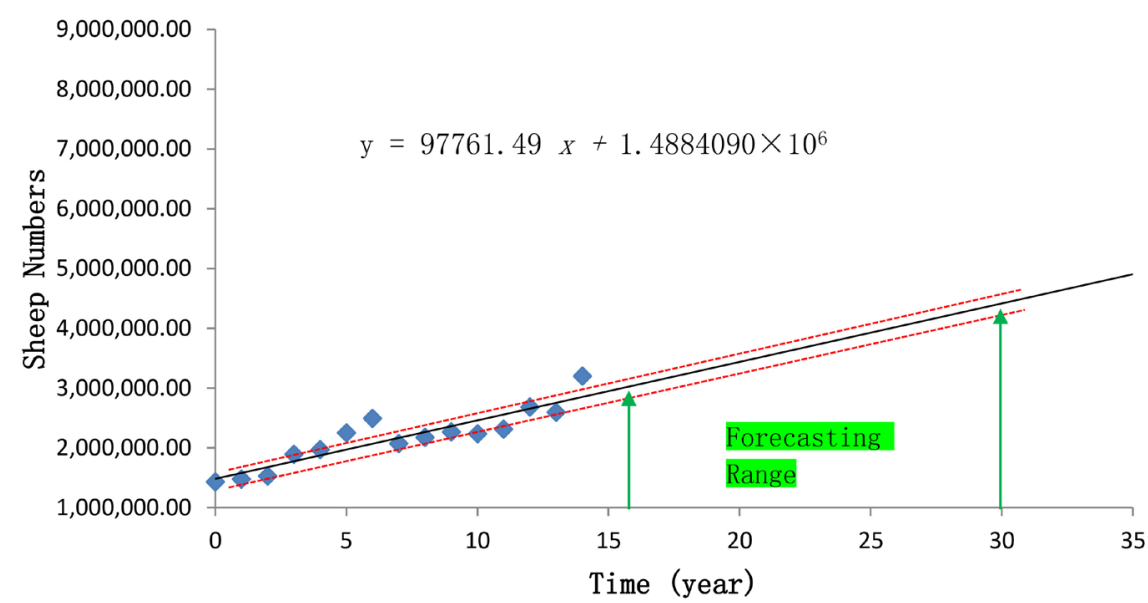

Figure 3. The results of the exponential growth model showing the real data of sheep number compared to the predicted values and the forecasting sheep number.

The interpretation of mean absolute percentage error MAPE values was suggested by Lewis [15] as follows: Less than $10 \%$ is highly accurate forecasting, $10 \%$ to $20 \%$ is good forecasting, $21 \%$ to $50 \%$ is reasonable forecasting and $51 \%$ and above is inaccurate forecasting. Values of MAPE for both models are less than $10 \%$, which can be considered, according to Lewis (1982) [15], to be highly accurate forecasting models (Table 2).

The results on sheep number prediction between 2017 and 2030 are shown in Table 3 and Figure 2 \& Figure 3. For long-term prediction, exponential model gives high predicted numbers as compared with that predicted from linear regression model. In 2030, exponential model predicts the sheep number to be $6,018,282$, while the linear regression model gives a value of $4,221,412$. Therefore, to minimize the risk of over prediction of sheep numbers, we considered using the linear regression model for further analysis.

\subsection{Major Losses Due to Wool-Waste}

The major losses due to wasted wool are divided into two categories. The first 
Table 2. Comparison between actual data on sheep number and prediction of both exponential and linear regression models.

\begin{tabular}{ccccccc}
\hline \multirow{2}{*}{ Year } & $\boldsymbol{t}$ & Actual Sheep Number & \multicolumn{2}{c}{ Exponential Model } & \multicolumn{2}{c}{ Linear Regression Model } \\
\cline { 5 - 7 } & & & Prediction & $\begin{array}{c}\text { Absolute } \\
\text { Error }\end{array}$ & Prediction & $\begin{array}{c}\text { Absolute } \\
\text { Error }\end{array}$ \\
\hline 2002 & 0 & $1,433,320$ & $1,484,090$ & 3.54 & $1,484,090$ & 3.54 \\
2003 & 1 & $1,476,450$ & $1,560,181$ & 5.67 & $1,581,851$ & 7.14 \\
2004 & 2 & $1,529,100$ & $1,640,173$ & 7.26 & $1,679,613$ & 9.84 \\
2005 & 3 & $1,890,450$ & $1,724,267$ & 8.79 & $1,777,374$ & 5.98 \\
2006 & 4 & $1,971,510$ & $1,812,672$ & 8.06 & $1,875,136$ & 4.89 \\
2007 & 5 & $2,251,440$ & $1,905,609$ & 15.36 & $1,972,897$ & 12.37 \\
2008 & 6 & $2,493,360$ & $2,003,312$ & 19.65 & $2,070,659$ & 16.95 \\
2009 & 7 & $2,070,930$ & $2,106,024$ & 1.69 & $2,168,420$ & 4.71 \\
2010 & 8 & $2,175,680$ & $2,214,002$ & 1.76 & $2,266,182$ & 4.16 \\
2011 & 9 & $2,264,630$ & $2,327,516$ & 2.78 & $2,363,943$ & 4.39 \\
2012 & 10 & $2,233,970$ & $2,446,851$ & 9.53 & $2,461,705$ & 10.19 \\
2013 & 11 & $2,311,150$ & $2,572,303$ & 11.30 & $2,559,466$ & 10.74 \\
2014 & 12 & $2,680,260$ & $2,704,188$ & 0.89 & $2,657,228$ & 0.86 \\
2015 & 13 & $2,596,450$ & $2,842,835$ & 9.49 & $2,754,989$ & 6.11 \\
2016 & 14 & $3,198,930$ & $2,988,590$ & 6.58 & $2,852,751$ & 10.82 \\
Mean absolute percentage error & & 7.49 & & 7.51 \\
\hline
\end{tabular}

Table 3. The results on sheep number prediction between 2017 and 2030.

\begin{tabular}{llcc}
\hline \multirow{2}{*}{ Year } & $\boldsymbol{t}$ & Exponential Model & Linear Regression Model \\
\cline { 3 - 4 } 2017 & 15 & Prediction & Prediction \\
2018 & 16 & $3,141,819$ & $2,950,512$ \\
2019 & 17 & $3,302,903$ & $3,048,274$ \\
2020 & 18 & $3,472,246$ & $3,146,035$ \\
2021 & 19 & $3,650,272$ & $3,243,797$ \\
2022 & 20 & $3,837,426$ & $3,341,558$ \\
2023 & 21 & $4,034,175$ & $3,439,320$ \\
2024 & 22 & $4,241,011$ & $3,537,081$ \\
2025 & 23 & $4,458,453$ & $3,634,843$ \\
2026 & 24 & $4,687,043$ & $3,732,604$ \\
2027 & 25 & $4,927,352$ & $3,830,366$ \\
2028 & 26 & $5,179,983$ & $3,928,127$ \\
2029 & 27 & $5,445,566$ & $4,025,889$ \\
2030 & 28 & $5,724,767$ & $4,123,650$ \\
\hline
\end{tabular}


category is the cost of wool collection and the second is the cost of the process of disposal. The sheep breeder bears the financial losses of wool collection and part of waste disposal, while the environment and the corresponding environmental agencies bear the effect of disposing the huge amount of waste. Table 4 shows the amount of wool produced between the years (2002-2016), the cost of the collection process, and the number of sheep each year obtained from DOS [13]. Applying these data, the corresponding specific cost of wool collection $(\mathrm{JD} / \mathrm{kg}$ ), and the yearly wool produced $(\mathrm{kg} / \mathrm{head})$ are calculated and reported in Table 4 . Taking the calculated average cost of collecting (mowing) $1 \mathrm{~kg}$ of wool to be 0.39 JD, (Table 4), and assuming the selling price of wool produced per head is 1JD, if suitable market is available [11], then total financial loss is calculated by adding the cost of collection to the estimated farmers' financial loss due to market un-availability and shown in Table 4.

The average of annual wool production $(1.89 \mathrm{~kg} / \mathrm{head})$ and the average of the collected wool costs $(0.39 \mathrm{JD} / \mathrm{kg})$, shown in (Table 4) were used to estimate their corresponding values for the years (2017-2030) and were presented in Table 5. The estimated total financial losses were, also, obtained by adding the financial losses due to lack of market availability to the collection costs (Table 5).

The second part of losses is due to random disposal of the mowed fleece by

Table 4. Wool produced and total cost of collection in Jordan (2002-2016) and the corresponding cost of wool $(\mathrm{JD} / \mathrm{kg})$, in addition to yearly wool produced $(\mathrm{kg} / \mathrm{head})\left({ }^{\star} \mathrm{Data}\right.$ obtained from reference [13]).

\begin{tabular}{ccccccc}
\hline Year & $\begin{array}{c}\text { Yearly wool } \\
\text { produced } \\
\text { (ton) }\end{array}$ & $\begin{array}{c}\text { Total cost of } \\
\text { collection* }^{*} \text { (JD) }\end{array}$ & $\begin{array}{c}\text { Cost of wool } \\
\text { collection } \\
\text { JD/kg }\end{array}$ & $\begin{array}{c}\text { Number } \\
\text { of sheep }\end{array}$ & $\begin{array}{c}\text { Wool produced } \\
\text { per head } \\
\text { (kg/head) }\end{array}$ & $\begin{array}{c}\text { Total financial } \\
\text { loss by breeders } \\
(\times 1000 ~ J D)\end{array}$ \\
\hline 2002 & 3260 & $1,255,050$ & 0.38 & $1,433,320$ & 2.27 & 2688 \\
2003 & 2889 & $1,487,358$ & 0.51 & $1,476,450$ & 1.96 & 2964 \\
2004 & 2860 & $1,231,841$ & 0.43 & $1,529,100$ & 1.87 & 2761 \\
2005 & 4421 & $2,166,102$ & 0.49 & $1,890,450$ & 2.34 & 4056 \\
2006 & 3535 & $1,607,350$ & 0.45 & $1,971,510$ & 1.79 & 3579 \\
2007 & 3785 & $1,537,445$ & 0.41 & $2,251,440$ & 1.68 & 3788 \\
2008 & 4534 & $1,972,859$ & 0.44 & $2,493,360$ & 1.82 & 4466 \\
2009 & 2588 & $1,088,609$ & 0.42 & $2,070,930$ & 1.25 & 3160 \\
2010 & 6857 & $2,546,860$ & 0.37 & $2,175,680$ & 3.15 & 4723 \\
2011 & 3953 & $1,408,926$ & 0.36 & $2,264,630$ & 1.75 & 3674 \\
2012 & 3268 & $1,159,903$ & 0.35 & $2,233,970$ & 1.46 & 3394 \\
2013 & 6553 & $2,444,568$ & 0.37 & $2,311,150$ & 2.84 & 4756 \\
2014 & 4311 & $1,315,048$ & 0.31 & $2,680,260$ & 1.61 & 3995 \\
2015 & 3133 & 984,391 & 0.31 & $2,596,450$ & 1.21 & 3581 \\
2016 & 4254 & $1,360,169$ & 0.32 & $3,198,930$ & 1.33 & 4559 \\
Average & 4013 & $1,571,099$ & 0.39 & $2,171,842$ & 1.89 & 3743 \\
\hline & & & & & & \\
\hline
\end{tabular}


Table 5. Predicted number of sheep and the associated estimated values of produced wool, cost of collection, farmers' loss due to lack of market un-availability, and the total financial loss by farmers.

\begin{tabular}{|c|c|c|c|c|c|}
\hline Year & $\begin{array}{l}\text { Predicted } \\
\text { number of } \\
\text { Sheep }\end{array}$ & $\begin{array}{l}\text { Estimated wool } \\
\text { produced (ton) }\end{array}$ & $\begin{array}{c}\text { Estimated cost } \\
\text { of collection by } \\
\text { farmers }(\times 1000 \\
\text { JD })\end{array}$ & $\begin{array}{c}\text { Estimated farmers' loss } \\
\text { due to lack of market } \\
\text { un-availability }(\times 1000 \\
\text { JD) }\end{array}$ & $\begin{array}{l}\text { Estimated total } \\
\text { financial loss by } \\
\text { farmers }(\times 1000 \\
\text { JD) }\end{array}$ \\
\hline 2017 & $2,950,512$ & 5577 & 2175 & 5577 & 7752 \\
\hline 2018 & $3,048,274$ & 5761 & 2247 & 5761 & 8008 \\
\hline 2019 & $3,146,035$ & 5946 & 2319 & 5946 & 8265 \\
\hline 2020 & $3,243,797$ & 6131 & 2391 & 6131 & 8522 \\
\hline 2021 & $3,341,558$ & 6316 & 2463 & 6316 & 8779 \\
\hline 2022 & $3,439,320$ & 6500 & 2535 & 6500 & 9035 \\
\hline 2023 & $3,537,081$ & 6685 & 2607 & 6685 & 9292 \\
\hline 2024 & $3,634,843$ & 6870 & 2679 & 6870 & 9549 \\
\hline 2025 & $3,732,604$ & 7055 & 2751 & 7055 & 9806 \\
\hline 2026 & $3,830,366$ & 7239 & 2823 & 7239 & 10,062 \\
\hline 2027 & $3,928,127$ & 7424 & 2895 & 7424 & 10,319 \\
\hline 2028 & $4,025,889$ & 7609 & 2968 & 7609 & 10,577 \\
\hline 2029 & $4,123,650$ & 7794 & 3040 & 7794 & 10,834 \\
\hline 2030 & $4,221,412$ & 7979 & 3112 & 7979 & 11,091 \\
\hline Average & $3,585,962$ & 6778 & 2643 & 6778 & 9421 \\
\hline
\end{tabular}

farmers. They collect the wool in medium size bags and dump them randomly at the sides of roads or dry valleys or through random burning process.

Their losses here are due to transportation cost. In addition to this, the environment suffers through land pollution due to random dumping, and air pollution due to the produced gases resulting from the burning of wool. Figure 4 shows a sample of disposed wool along the highway sides in Mafraq governorate [16]. Farmers suffer financially and physically, and they ask the Government for help to find possible industrial processes for their vast wool product [16]. Therefore, if this problem is not solved, livestock breeding will be at risk, the level of unemployment will increase, and rural area population will be partially depleted due to migration to the city.

\subsection{Physical Characteristics of Jordanian Sheep Wool}

Thermal characteristics represent the most important factor to decide the suitability of the material of being competitive to be used as an insulation material. Characterization of many insulation materials has been reported in literature [3] [17] [18]. In this study the thermal characteristics of Jordanian sheep wool were investigated and compared to other synthetic thermal insulation materials used by construction sector in Jordan. 


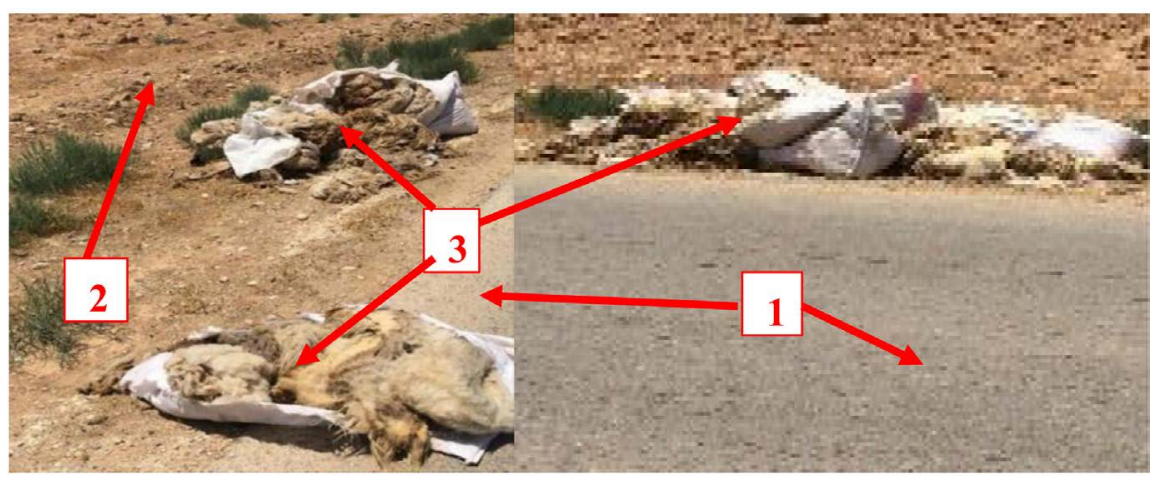

Figure 4. Wool disposal as a solid waste: 1. Mafraq main highway, 2. Farmland, 3. Fleece disposed waste [16].

Thermal conductivity of sheep wool was examined using heat transfer experimental module (Armfield Co., UK). A schematic of heat conduction experiment is shown in Figure 5. Values of thermal conductivities of sheep wool, Polystyrene boards of $3 \mathrm{~cm}$ thickness, and rockwool were obtained applying the following equation:

$$
k=\frac{L}{A\left(T_{\text {hot }}-T_{\text {cold }}\right)} \dot{Q}
$$

where: $k$ is thermal conductivity $(\mathrm{W} / \mathrm{m} \cdot \mathrm{K}), L$ : thickness of specimen $(m), A$ is cross sectional area $\left(1 \mathrm{~m}^{2}\right)$, and $\dot{Q}$ is Heat flux = Electric power supply (W)

Based on this equation and the data from the above experiment, thermal conductivity of Jordanian sheep-wool was $0.033 \pm 0.002 \mathrm{~W} / \mathrm{m} \cdot \mathrm{K}$ compared to $0.0 .032 \pm 0.002 \mathrm{~W} / \mathrm{m} \cdot \mathrm{K}$, and $0.034 \pm 0.002 \mathrm{~W} / \mathrm{m} \cdot \mathrm{K}$, for $0.03 \mathrm{~m}$ polystyrene board thickness specimens and rockwool, respectively. Results are reported in Table 6. The thermal resistance $R$ of the three materials was calculated using the following equation:

$$
R=\frac{L}{k A}\left({ }^{\circ} \mathrm{C} / \mathrm{W}\right)
$$

Obtained $R$ values for $L=0.05 \mathrm{~m}(R-5)$ are reported in Table 6. Sheep-wool thermal resistance is $1.515 \pm 0.002 \mathrm{~K} / \mathrm{W}$, whereas it is $1.563 \pm 0.002 \mathrm{~K} / \mathrm{W}$ for polystyrene, and $1.471 \pm 0.002 \mathrm{~K} / \mathrm{W}$ for rockwool sample.

Ignition temperature for sheep wool, polystyrene, and rockwool were measured using a temperature-controlled muffle furnace $\left(100^{\circ} \mathrm{C}-1200^{\circ} \mathrm{C}\right)$. Each sample was placed in the furnace, and temperature is increased in steps of $\left(25^{\circ} \mathrm{C}\right)$. Then, the temperature was left to equilibrate, and the sample was observed at equilibrium state for $120 \mathrm{~s}$. If no ignition is observed the temperature is increased for the next equilibrium state repeatedly until ignition is achieved. The ignition temperature of sheep wool was found to be $\left(550^{\circ} \mathrm{C} \pm 12.5^{\circ} \mathrm{C}\right)$, whereas, it was $\left(800^{\circ} \mathrm{C} \pm 12.5^{\circ} \mathrm{C}\right)$ for rockwool, and $\left(500^{\circ} \mathrm{C} \pm 12.5^{\circ} \mathrm{C}\right)$ for polystyrene which was observed to melt at about $100^{\circ} \mathrm{C}$ (Table 6).

Sheep-wool is a good material to maintain constant relative humidity indoors because of the possibility of absorbing up to $35 \%$ by weight without sensation of 


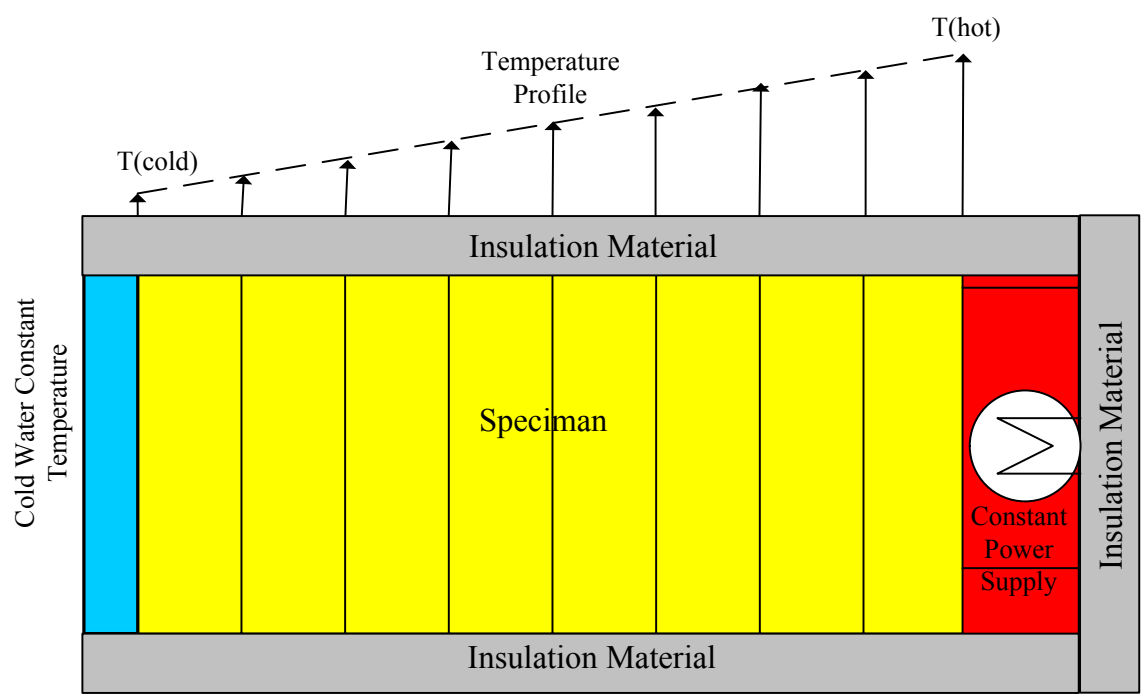

Schematic of Heat Conduction Experiment

Figure 5. Schematic of heat conduction experiment for thermal conductivity measurements.

Table 6. Thermal characteristics of Jordanian sheep-wool compared to other synthetic thermal insulation materials used by construction sector.

\begin{tabular}{cccc}
\hline Material & $\begin{array}{c}\text { Thermal Conductivity } \\
(\mathrm{W} / \mathrm{m} \cdot \mathrm{K})\end{array}$ & $\begin{array}{c}\text { Thermal Resistance }(R-5) \\
(\mathrm{K} / \mathrm{W})\end{array}$ & $\begin{array}{c}\text { Ignition Temperature* } \\
\left({ }^{\circ} \mathrm{C}\right)\end{array}$ \\
\hline Sheep-Wool & $0.033 \pm 0.002$ & $1.515 \pm 0.002$ & $550 \pm 12.5$ \\
Polystyrene & $0.032 \pm 0.002$ & $1.563 \pm 0.002$ & $500 \pm 12.5$ \\
Rockwool & $0.034 \pm 0.002$ & $1.471 \pm 0.002$ & $800 \pm 12.5$ \\
\hline
\end{tabular}

${ }^{*}$ Melting point of polystyrene was observed at $100^{\circ} \mathrm{C}$.

humidity, followed be desorption process for humidification [3] [18]. Moreover, sheep-wool is considered as an excellent acoustic insulation material for buildings [18] [19].

\section{Possible Processes to Manufacture Fleece Product Ready for Marketing}

Several approaches are possible processes to manufacture fleece product with acceptable revenues. However, a limited number of such approaches are feasible in the case of Jordanian fleece. One approach involves fleece collection, packaging, and marketing. This approach has been studied by "Productivity Promotion Centers" (IRADA), Jordanian Government, in 2003 [10], which was presented for investment purposes to establish a firm in Mafraq Governorate. Unfortunately, it failed to attract any investor, despite the provision of many government incentives. The second possible approach, which has never been proposed in Jordan, involves fleece collection, washing, and either to be used as buildings insulation material or blanket and mattress manufacturing. Cloth production from wool may be considered as another approach; however Jordanian sheep 
wool is not suitable for the cloth industry.

\section{Infrastructure Availability for Investment}

Jordan Industrial Cities Company was established in 2008 as a successor to the Jordan Industrial Estates Corporation, which was established in 1980 as one of the contributors to the national economy, and promoters to Jordan as a suitable environment for investment. The Industrial Cities Company provides elements of the integrated infrastructure for investment. They are distributed all over the country, especially in Mafraq (Northern Region), which has the largest number of sheep (Figure 1), Amman (Central Region) and Karak (Southern Region). Consequently, the presence of industrial cities in the densest areas for sheep, increases the feasibility of producing sustainable sheep-wool products.

All Industrial Cities include a complete infrastructure that involves internal roads, besides, electric, communications, water, sanitary, and rain drainage networks. They also include all necessary Governmental offices to provide easy and fast services. Moreover, the Jordanian Government reduces income tax to 5\%, sales tax to $0 \%$, custom tax to $0 \%$, community service tax to $0 \%$ and shares profit distribution tax to $0 \%$ for all industrial activities carried out within industrial cities. Also, hangars necessary to construct production lines within these cities can be rented or bought at preferential rates.

\section{Results and Discussion}

Although collection of wool from sheep can be an important pillar of farmers' income as well as a significant contributor to the Gross National Income, however at this stage it causes a significant problem to both; farmers and the Government. Table 1 shows the distribution of Sheep within the northern, central, southern regions of Jordan between the years 2002-2016. The northern region accounted for $41 \%$ of the total, while the central region accounted for $38 \%$ and the southern region accounted for about $21 \%$. Mafraq Governorate accounts for about $75 \%$ of the total number of Sheep within northern region. This may indicate that any possible wool industry is better to be located within Mafraq Area, especially it contains an industrial city that will provide the required infrastructure and the associated investments incentives. Sheep holdings in the southern region are low compared to northern and central regions, although the area of Ma'an Governorate accounts for 33\% of the area of Jordan. This may suggest that possible utilization of sheep-wool as an insulation material in construction sector may enhance sheep breeding in this area, which will lead to create significant number of employment opportunities, where the recent percentage of un-employment reaches about $30 \%$.

Exponential growth model was compared against linear regression model to predict number of sheep as a function of time. Table 2 and Figure 3 \& Figure 4 compare the actual data for the period 2002-2016 to the predicted values for the same period. Uncertainty analysis is based on MAPE calculations resulted in an 
average value for both models less than $10 \%$, which is considered, according to reference [15] highly accurate forecasting. However, as mentioned above, the linear regression model was favored above exponential growth model to avoid large discrepancies associated with long times under consideration. The average increase in actual sheep number for the 15 years period (2002-2016) is observed to be $123 \%$, compared to a $92 \%$ increase for predicted results. Therefore, with this result and MAPE analysis, sustainability of wool production seems to be promising. Table 3 presents results of predicted number of sheep for the period 2017-2030 for both models, from which, regression model results are adopted for this study, with a $43 \%$ increase for the 14 years period.

The annual average number of sheep for the period 2002-2016 is 2,171,842 with an annual average collection cost 1,571,099 JD (Table 4), which leads to an average collection cost per $\mathrm{kg}$ to be $0.39 \mathrm{JD}$. As mentioned above, interviews with farmers indicated that wool can be sold at an average value of $1 \mathrm{JD}$ for the wool amount produced per head. Therefore, an average annual financial loss is calculated for the period 2002-2016 to be about $3743 \times 10^{3} \mathrm{JD} /$ year. This annual loss is reflected on higher prices of other farming products in the National Market, and hence, the National Economy will be negatively affected as well.

Based on the data presented in Table 4, an average value of wool produced per head was obtained to be $1.89 \mathrm{~kg} / \mathrm{h}$ ead, which is different from the reported value of $2.5 \mathrm{~kg} /$ head reported by reference 10 , however this estimated value lies within the reported literature values 1.5 to $3 \mathrm{~kg}$. Results presented in Table 5 show a predicted annual average number of sheep was obtained to be 3,585,962 for the period 2017-2030 based on linear regression model. The annual estimated average of produced wool is 6778 ton, leading to an estimated total annual average loss of $9421 \times 10^{3} \mathrm{JD}$. This loss is borne by the farmer, which will be borne by the consumer through other farm products of meat, milk and cheese. Moreover, the methods by which farmers dispose such huge amounts of wool, as mentioned above (Figure 4), create a continuing environmental problem that requires costly efforts borne on both, the farmer and the governmental environmental protection agencies. This environmental problem, if not solved, will affect the future of the livestock in Jordan. It will lead to force sheep breeders to abandon this profession in favor of finding other ways of living in the city, which will increase the rate of migration from rural area, and hence, will lead to an increase in un-employment rate. Eventually, livestock sector and the National Economy will suffer.

Starting wool industry in Jordan is one way to solve the above discussed problems. The study conducted in 2003 [10] that involved investment opportunities by wool collecting and exporting, as raw material, was found un-acceptable, despite the governmental incentives. Moreover, wool obtained from Awassi sheep (the major breed in Jordan) is best to be utilized in carpet and blanket industries because of its characteristics as mentioned above in the introduction. Therefore, different methods to handle this type of wool are to be considered. Two ap- 
proaches can be considered to start wool industry in, Jordan; the first approach involves establishment of Green Buildings insulation sheets industry that can be used in construction of buildings, and the second approach is to establish a carpet and blanket industry. This can be done by transferring technology required to construct the corresponding production lines, and the establishment of such industries will avoid just exporting wool as non-marketable raw material. Moreover, massive construction expansion in Jordan due to forced immigration from neighboring countries in addition to the need of neighboring countries to rebuild after catastrophic wars indicates that the insulation material market will be favored over carpet blanket industry. Besides that, all the materials recently used in insulation for construction purposes are imported from outside the country. Therefore, insulation material industry is seen to be favored over the carpet and blanket industry which will be an option for the future. Machines and equipment required to start insulation industry are well established products worldwide, especially in China, and can be ready to be imported to build a production line, in addition to the available infrastructure within industrial cities and the different incentives given by the government of Jordan.

Because the number of sheep in Mafraq governorate is the largest in Jordan which accounts for $31 \%$ of the total (Figure 1), and the northern region including Mafraq accounts for $41 \%$ (Table 2), therefore, the optimum location for such an industry could be the industrial city of Mafraq. Sustainability of insulation industry with respect to wool availability is clearly seen from the results of the regression model and MAPE analysis that estimates the number of sheep for the period 2017-2030 (Table 5). An annual average number of sheep was predicted to be 3,585,962 head, and the corresponding estimated annual average wool produced is 6778 ton, which indicates a continuing source of wool to sustain the required raw material of this industry.

A recent report issued by the Jordanian Ministry of Agriculture included signing an agreement with the United Nations Development Program (UNDP) in March 2019 [19]. It involves in implementation of a project to enhance the productivity and quality of sheep-wool in the Jordan desert. The program will last for three years with a total project funding of 1.84 million JD (2.6 million US\$). It covers training of required employees on the new methods of mowing and collecting fleece with modern mechanization [19]. This also requires an employment of some veterinarians to supervise the mowing of wool to maintain animal safety. Therefore, employment opportunities will be created, which will be reflected on the National Economy. Moreover, starting a project involves production of insulation material from sheep-wool will be an added value to the new strategy of the Ministry of Agriculture towards "Rehabilitation of Badia (Jordanian Desert)".

Environmental impact of the current situation will be completely overcome if sheep-wool is used to produce insulation material or any other future possible product such as carpet and blanket industry. Achieving this goal will reduce the 
financial loss borne on the farmer as well as the National Environmental Agencies. Therefore, there will be a significant added value to the National Economy. Landfill and water harvesting within Jordanian Badia will recover from the current impact of random disposal of wasted sheep-wool. As a result, the sheep breeders will have an environmental practice through mowing the wool in scientific ways that are harmless to the animal, under the supervision of veterinarians, and easily marketing the product to the line or lines of production. Moreover, production of thermal insulation material from sheep-wool will have a major contribution toward "Rehabilitation of Badia" and agrees well with the strategy launched by the Government of Jordan. Similar cases worldwide will benefit from the result of this study.

Comparing sheep-wool as a green building insulation material with popular material recently used in construction sector of Jordan, such as polystyrene boards of $3 \mathrm{~cm}$ thickness and rockwool, we find that sheep wool is better than both. Thermal conductivity data shows competitive values of sheep-wool to the other two. Also, its ignition temperature is high enough to be considered safe $\left(550^{\circ} \mathrm{C}\right)$. Polystyrene has low melting point $\left(100^{\circ} \mathrm{C}\right)$, and rockwool may affect the respiratory system of people, therefore they can be considered less competitive than sheep-wool. Both polystyrene and rockwool are either imported, in the case of Jordan, or the starting material are imported, while sheep-wool is renewably produced leading to lower the cost of insulation material. Therefore, utilization of sheep-wool in green building insulation material is better than other competitive materials.

Based on the above points, Jordanian sheep wool collection and disposal have an obvious financial cost with deleterious environmental impacts. Such raw material is abundantly available throughout Jordan, and the highest is within Mafraq governorate. Continuing disposing the waste, obviously, will have negative impact on sheep-breeding industry as well as the National income. Physical characteristics of sheep wool show that it can be an excellent replacement choice of imported polystyrene and rockwool as construction insulation material. These results can be further used to do cost-benefit analysis and complete sheep wool construction insulation material plant design within Mafraq governorate as a case study.

\section{Conclusion}

Sustainability of Jordanian sheep wool, as a source of construction insulation material, can be a possible solution to the recent problems associated with wool waste. The results of this study are applicable to similar cases worldwide.

\section{Acknowledgements}

The authors wish to thank Jordanian sheep breeders within Karak governorate for responding to the planned interviews, and his excellency Dr. Sabri Rbeihat for fruitful discussions on sheep breeding in Tafila governorate. 


\section{Conflicts of Interest}

The authors declare no conflicts of interest regarding the publication of this paper.

\section{References}

[1] Pollott, G. and Trevor, R.W. (2009) Sheep and Goats for Diverse Products and Profits. Food and Agriculture Organization of the United Nations (FAO), Roma.

[2] Hirsch, S. (1933) Sheep and Goats in Palestine. Palestine Economic Society, Tel Aviv.

[3] Korjenic, A., Klarić, S., Hadžić, A. and Korjenic, S. (2015) Sheep Wool as a Construction Material for Energy Efficiency Improvement. Energies, 8, 5765-5781. https://doi.org/10.3390/en8065765

[4] Galal, S., Gursoy, O. and Shaat, I. (2008) Awassi Sheep as a Genetic Resource and Efforts for Their Genetic Improvement-A Review. Small Ruminant Research, 79, 99-108. https://doi.org/10.1016/j.smallrumres.2008.07.018

[5] Epstein, H. (1982) World Animal Review: Awassi Sheep. A Quarterly Journal on Animal Health Production and Products No. 44.

[6] Holman, B.W.B. and Malau-Aduli, A.E.O. (2012) A Review of Sheep Wool Quality Traits. Annual Review \& Research in Biology, 2, 1-14.

[7] Qtaishat, T., Al-Sharafat, A. and Majdalawi, M.I. (2012) A Comparative Economic Analysis of Sheep Production Systems: A Case Study of Jordan. Journal of Food, Agriculture \& Environment, 10, 690-694.

[8] Housawi, F.M.T. and Abu Elzein, E.M.E. (2000) Contagious Ecthyma Associated with Myiasis in Sheep. Revue Scientifique et Technique, 19, 863-866. https://doi.org/10.20506/rst.19.3.1259

[9] Gootwine, E. (2011) Mini Review: Breeding Awassi and Assaf Sheep for Diverse Management Conditions. Tropical Animal Health and Production, 43, 1289-1296. https://doi.org/10.1007/s11250-011-9852-y

[10] Productivity Promotion Centers (2003) Preliminary Feasibility Study: Project of Collecting and Marketing Sheep Wool, Mafraq Area, Jordan.

[11] Personal Interviews with Sheep Breeders Conducted by the Authors, 2019, Jordan.

[12] Zametica, M., Klarić, E. and Klarić, S. (2016) The Feasibility Study for the Project of Production of Thermal Insulation Materials Made from Sheep Wool. Savjet za zelenu gradnju-Green Council Sarajevo.

[13] Department of General Statistics (DOS) (2016) Annual Statistical Bulletin, Agricultural Section, Jordan.

[14] Zabadi, A., Assaf, R. and Kanan, M. (2017) A Mathematical and Statistical Approach for Predicting the Population Growth. Worldwide Journal of Multidisciplinary Research and Development (WWJMRD), 3, 50-59.

[15] Lewis, C.D. (1982) International and Business Forecasting Method; A Practical Guide to Exponential Smoothing and Curve Fitting. Butterworth Scientific, London.

[16] Abu Summaqah, T. (2018) A Report Published through Jordan News Agency (PETRA) via Al-Rai Official Newspaper.

[17] Parlato, M.C.M. and Porto, S.M.C. (2020) Organized Framework of Main Possible Applications of Sheep Wool Fibers in Building Components. Sustainability, 12, 761-778. https://doi.org/10.3390/su12030761 
[18] Dénes, O., Florea, I. and Manea, D.L. (2019) Utilization of Sheep Wool as a Building Material. Procedia Manufacturing, 32, 236-241.

https://doi.org/10.1016/j.promfg.2019.02.208

[19] Project to Rehabilitate Badia (Jordan Desert), Government of Jordan, Ministry of Agriculture (2019) A Report Broadcasted by Jordan Official Broadcasting Station Almamlaka. https://www.almamlakatv.com/news/ 